University of Nebraska - Lincoln

DigitalCommons@University of Nebraska - Lincoln

\title{
Using Aquatic Invertebrates to Delineate Seasonal and Temporary Wetlands in the Prairie Pothole Region of North America
}

Ned H. Euliss Jr.

U.S. Geological Survey, ceuliss@usgs.gov

David M. Mushet

U.S. Geological Survey, dmushet@usgs.gov

Douglas H. Johnson

U.S. Geological Survey, Douglas_H_Johnson@usgs.gov

Follow this and additional works at: https://digitalcommons.unl.edu/usgsnpwrc

Euliss, Ned H. Jr.; Mushet, David M.; and Johnson, Douglas H., "Using Aquatic Invertebrates to Delineate Seasonal and Temporary Wetlands in the Prairie Pothole Region of North America" (2002). USGS Northern Prairie Wildlife Research Center. 267.

https://digitalcommons.unl.edu/usgsnpwrc/267

This Article is brought to you for free and open access by the US Geological Survey at DigitalCommons@University of Nebraska - Lincoln. It has been accepted for inclusion in USGS Northern Prairie Wildlife Research Center by an authorized administrator of DigitalCommons@University of Nebraska - Lincoln. 


\title{
USING AQUATIC INVERTEBRATES TO DELINEATE SEASONAL AND TEMPORARY WETLANDS IN THE PRAIRIE POTHOLE REGION OF NORTH AMERICA
}

\author{
Ned H. Euliss, Jr., David M. Mushet, and Douglas H. Johnson \\ U.S. Geological Survey \\ Northern Prairie Wildlife Research Center \\ 871137 Street $S E$ \\ Jamestown, North Dakota, USA 58401
}

\begin{abstract}
Tillage can destroy or greatly disturb indicators of hydric soils and hydrophytic vegetation, making delineation of tilled wetlands difficult. The remains of aquatic invertebrates (e.g., shells, drought-resistant eggs, and trichopteran cases) are easily identifiable and persist in wetland substrates even when wetlands are dry. Additionally, these remains are not easily destroyed by mechanical tillage. To test the feasibility of using invertebrate remains to delineate wetlands, we used two methods to identify the wetland edge of ten seasonal and ten temporary wetlands, evenly divided between grassland and cropland landscapes. First, we identified the wetland edge using hydric soil and vegetation indicators along six evenly spaced transects in each wetland (our "standard" delineation). We then identified the wetland edge along the same transects using aquatic invertebrate remains as our indicator. In grassland landscapes, delineations of the wetland edge made using invertebrate remains were consistently at the same location or closer to the wetland center as the standard delineations for both seasonal and temporary wetlands. In cropland landscapes, however, many of our invertebrate delineations of seasonal and temporary wetlands were on the upland side of our standard delineations. We attribute the differences to movement of remains during tillage, increased maximum pool levels in cropland wetlands, and disturbance of hydric soils and plants. We found that the elevations of the wetland edge indicated by invertebrate remains were more consistent within a wetland than elevations determined by standard delineations. Aquatic invertebrate remains can be useful in delineating wetlands when other indicators have been destroyed or severely disturbed by tillage.
\end{abstract}

Key Words: aquatic invertebrates, invertebrate remains, prairie pothole region, resting eggs, shells, short hydroperiod, tillage, wetland delineation

\section{INTRODUCTION}

Wetlands are the only ecosystems regulated on public and private lands in the United States (National Research Council 1995). Thus, methods have been developed to define, identify, and delineate wetlands for regulatory purposes. Current wetland definitions emphasize three major wetland components: water, substrate, and biota. Determining the status of these three characteristics is the basis of current wetland identification and delineation methodologies. Of the three, wetland hydrology (i.e., water) deserves special status because, without the presence of water, neither hydric soils nor wetland biota can develop (National Research Council 1995). However, the presence of wetland hydrology is often the most difficult to measure and determine, so hydric soils and wetland biota are often used to infer wetland hydrology. In the case of wetland biota, this currently means relying exclusively on veg- etation, as other biotic indicators have not been developed.

Recent wetland delineation manuals (U.S. Army Corps of Engineers 1987, U.S. Environmental Protection Agency 1988, Federal Interagency Committee for Wetlands Delineation 1989, U.S. Department of Agriculture 1994) rely heavily on hydric soils and hydrophytic vegetation as indicators of wetland hydrology. However, many prairie pothole wetlands lack saturated soil conditions for much of their growing season and are often tilled and planted to an agricultural crop as part of normal farming operations. Due to difficulties in identifying hydric soils on glacial till, prairie pothole wetlands are specifically listed as problem areas in the U.S. Army Corp of Engineers wetland delineation manual (U.S. Army Corps of Engineers 1987). The problem is exacerbated by tillage, especially during drought years when even wetlands with more permanent water regimes become dry and are incorporated into farming plans. In addition to destroying or 


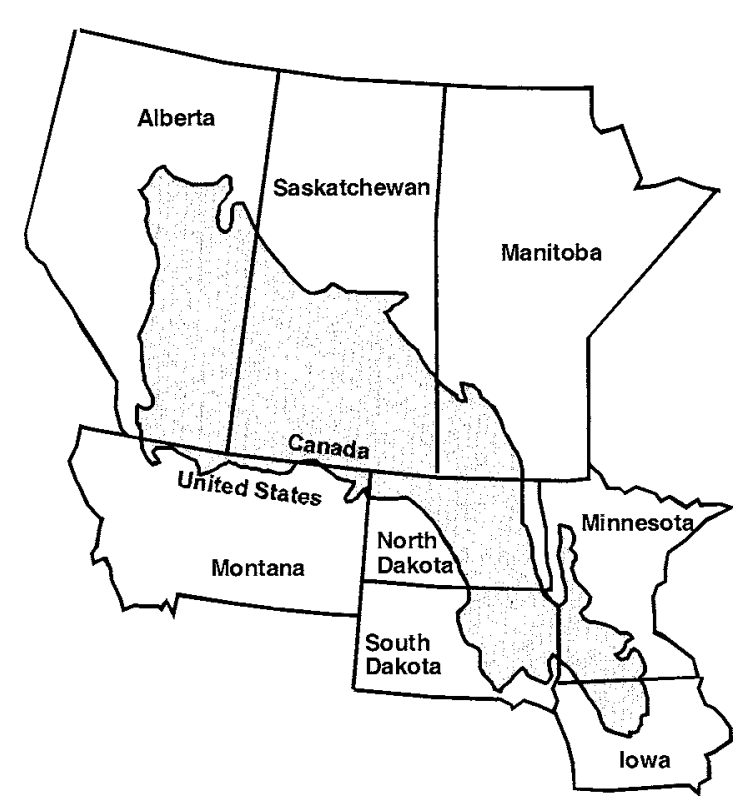

Figure 1. The prairie pothole region of North America.

greatly disturbing indicators of hydric soils, tillage also destroys or severely disturbs hydrophytic vegetation, adding to the difficulties in identifying and delineating these wetlands. Further, the use of herbicides in agricultural fields can exacerbate problems in delineating wetlands based on hydrophytic vegetation.

Due to the problems associated with hydric soils and plant indicators in tilled wetlands, a need exists to identify additional biotic indicators that are unique to wetlands, are easily identifiable, and are not easily destroyed by normal farming activities. Many invertebrates (e.g., water fleas, seed shrimp, clam shrimp, and various species of snails) are restricted to wetlands (Barnes 1968, Clarke 1981) and are specific to particular hydrologic regimes that define wetland classes (Euliss et al. 1999). Further, their remains (e.g., shells, chitinous exoskeletons, resistant eggs) are easily identifiable and persist in wetland substrates even when wetlands are dry. Moreover, these recalcitrant remains are not easily destroyed by mechanical tillage (Euliss and Mushet 1999). Hence, the remains of aquatic invertebrates reflect time-integrated information on wetland hydrology that may be useful to delineate wetlands in the prairie pothole region of North America.

This study is a follow-up to a study we conducted in 1992 and 1993 that demonstrated that invertebrate remains can be used to identify wetlands that are often dry and cultivated (Euliss et al. 2001). However, in the earlier study, we did not assess the potential of invertebrates as a delineation tool. We initiated the current study in 1995 to test the feasibility of using inverte- brate remains to delineate the edges of temporary and seasonal wetlands in the prairie pothole region.

\section{STUDY AREA}

The prairie pothole region covers about 715,000 $\mathrm{km}^{2}$, extending from north-central Iowa, USA to central Alberta, Canada (Figure 1). The landscape of the prairie pothole region is largely the result of Pleistocene glaciation. The landscape is dotted with numerous depressional wetlands caused by the uneven deposition of glacial sediments, the scouring action of glaciers, and the melting of buried ice blocks. The landscape has been substantially altered since European settlement beginning in the late 1800s. Economic incentives to convert natural landscapes to agriculture have been great resulting in the loss of over half of the original 8 million hectares of wetlands (Tiner 1984, Dahl 1990, Dahl and Johnson 1991). Land-use impacts on wetland biota include enhanced siltation, contamination from agricultural chemicals, altered hydrology, spread of exotic plants, and habitat fragmentation due to wetland drainage and conversion of native prairie grasslands into agricultural fields.

For this study, we selected ten seasonal and ten temporary wetlands (Stewart and Kantrud 1971) from $640-\mathrm{km}^{2}$ hexagons systematically overlain on the prairie pothole region of North Dakota as part of the U.S. Environmental Protection Agency's Environmental Monitoring and Assessment Program (U.S. Environmental Protection Agency 1993). For each wetland class (i.e., seasonal and temporary), we selected at random five wetlands located within tilled agricultural landscapes (in production for a minimum of ten years) and five additional wetlands located within undisturbed grassland landscapes. For purposes of this study, we limited our study sites to within those hexagons occurring within the glaciated plains of North Dakota (Figure 2), an area of intensive agricultural activity. Seasonal wetlands thus selected ranged in size from 0.1 ha to 0.8 ha and temporary wetlands ranged from 0.1 ha to 0.3 ha.

\section{METHODS}

Within each study wetland, we established six transects radiating from the center (defined as the lowest elevation in the basin) and extending $5 \mathrm{~m}$ beyond the wetland edge along evenly distributed compass bearings $\left(0^{\circ}, 60^{\circ}, 120^{\circ}, 180^{\circ}, 240^{\circ}\right.$, and $\left.300^{\circ}\right)$. For purposes of sample collection, the wetland edge was defined as the point along each transect where the elevation exceeded the elevation of maximum possible pool level by $15 \mathrm{~cm}$. Maximum possible pool level was defined as the elevation beyond which water would flow over- 


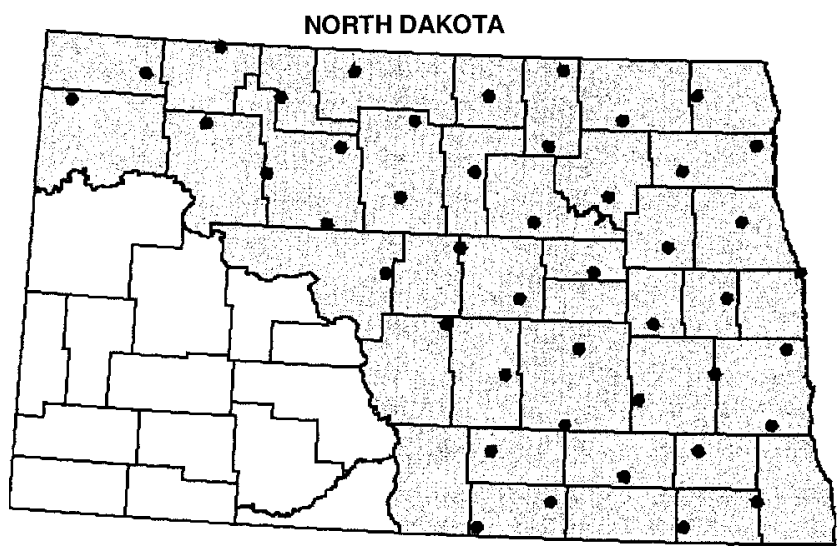

Figure 2. Location of U.S. Environmental Protection Agency's Environmental Monitoring and Assessment Program hexagons in the prairie pothole region (shaded) of North Dakota.

land into an adjacent basin. We collected a soil sample each meter along the entire length of each transect and measured the elevation at each point where samples were collected. Soil samples consisted of $500 \mathrm{ml}$ of soil collected with a trowel from the top $5 \mathrm{~cm}$ after removal of loose debris. All elevation measurements were obtained using a Spectra-Physics Model 650 Laserplane.

Along each transect, we also delineated the wetland edge using methods provided by the U.S. Army Corp of Engineers (1987). For this delineation (hereafter referred to as "standard delineation"), we often relied exclusively on indicators of hydric soils (U.S. Department of Agriculture 1996) and hydrophytic vegetation (Reed 1988) due to the absence of hydrologic indicators (e.g., watermarks, drift lines, sediment deposits, visual observation of saturation) in cropland wetlands. The distance from the wetland center to the wetland edge identified by the standard delineation and the relative elevation of the standard delineation were measured. We sampled each study wetland when their basins were dry and, in the case of the cropland wetlands, had been tilled or planted to an agricultural crop. Sampling of temporary wetlands was conducted between June 1 and July 26, 1995. Due to above-normal precipitation in 1995, most of our seasonal wetlands were flooded, so we delayed sampling of seasonal wetlands until the summer and fall (July 31 and October 1) of 1996 when they were dry.

We processed each soil sample by first sieving the sample through a $0.5-\mathrm{mm}$ screen to concentrate invertebrate remains. We then sorted the remains to determine the presence or absence of aquatic invertebrate remains (Table 1) in each concentrated sample. Not all collected samples were processed. Instead, we processed every fifth sample along a transect to allow us
Table 1. Types of aquatic invertebrate evidence used in delineating the wetland/upland edge of seasonal and temporary wetlands in the prairie pothole region.

\begin{tabular}{ll}
\hline \multicolumn{1}{c}{ Taxon } & Type of Evidence \\
\hline Planorbidae & Shells \\
Lymnaeidae & Shells \\
Physidae & Shells \\
Cladocera & Resting Eggs \\
Ostracoda & Shells \\
Trichoptera & Cases \\
\hline
\end{tabular}

to identify the area of interest (the wetland edge) quickly. We then processed all samples collected within $5 \mathrm{~m}$ of the last sample that contained aquatic invertebrate remains and the first sample that did not contain remains. For our delineation using invertebrate remains (hereafter referred to as "invertebrate delineation"), we defined the wetland/upland edge to be the location of the last soil sample along a transect that contained remains of aquatic invertebrates. We then compared distance from the wetland center and relative elevation of the invertebrate delineations to the standard delineations.

\section{RESULTS}

Seasonal Wetlands

Of the wetland delineations we made along 60 transects in seasonal wetlands (six transects in each of ten wetlands), 44 of the invertebrate delineations were within $2 \mathrm{~m}$ of the standard delineations (Figure 3). For the five seasonal wetlands in grassland, 12 of 30 of the invertebrate delineations were at the same location as the standard delineations, and 18 were closer to the wetland's center; not a single invertebrate delineation in grassland was on the upland side of the standard delineation (Figure 4). In the five cropland wetlands, six invertebrate delineations were at the same location as the standard delineations, while eight were on the wetland side and 16 were on the upland side (Figures 3 and 5). For both groups (seasonal wetlands in cropland and seasonal wetlands in grassland), the relative elevations of the invertebrate delineations were more consistent (i.e., had lower standard deviations) within wetlands than the elevations of the standard delineations (Figure 6). Even for individual wetlands, this held true with only one exception, a seasonal wetland in cropland.

\section{Temporary Wetlands}

Of the ten temporary wetlands we sampled, we were able to perform standard delineations in only seven, 


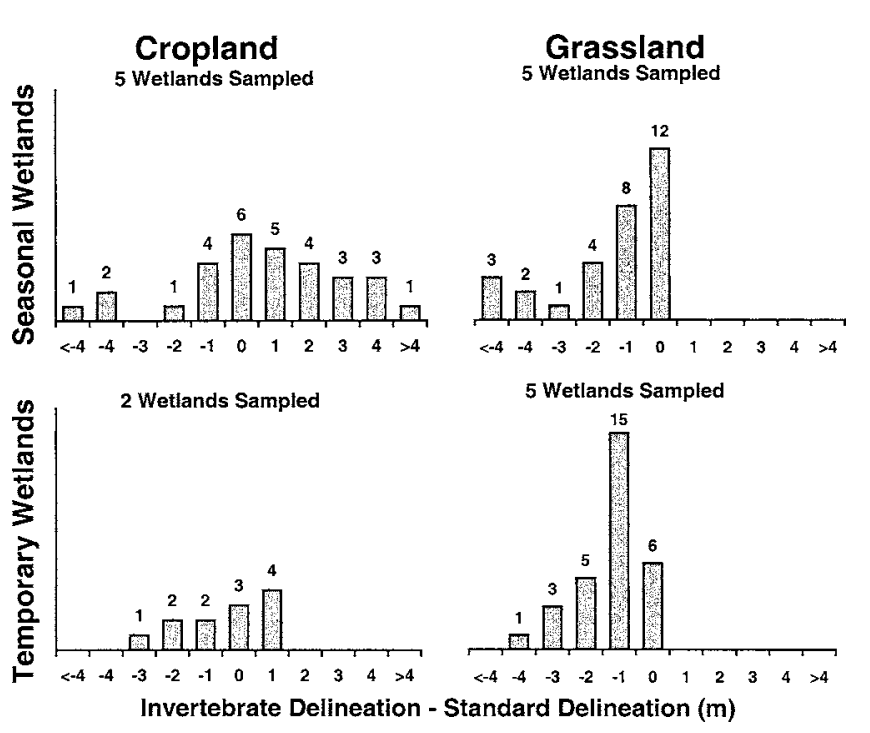

Figure 3. Distance $(\mathrm{m})$ between invertebrate delineations and standard delineations along six transects in each of ten seasonal and seven temporary wetlands in cropland and grassland landscapes of the glaciated plains, North Dakota, USA.

all five grassland wetlands and two cropland wetlands. We were unable to perform standard delineations in the three cropland wetlands due to severe disturbance of indicators by tillage. In two of these three wetlands, we were also unable to perform our invertebrate delineations due to an absence of invertebrate remains in our samples.

In the seven temporary wetlands in which we were able to perform both invertebrate and standard delineations, delineations followed the same general trends we observed for seasonal wetlands. Of the wetland delineations we made along the 42 transects (six transects in each of the seven temporary wetlands), 30 of the invertebrate delineations were within $1 \mathrm{~m}$ of the standard delineations and 37 were within $2 \mathrm{~m}$ (Figure 3). Just as for seasonal wetlands in grassland, all of the invertebrate delineations in the temporary wetlands in grassland were either at the same location as the standard delineations (6 of 30) or were closer to the wetland's center (the remaining 24). Once again, not a single invertebrate delineation was on the upland side of the standard delineation in grassland wetlands. In the two cropland wetlands for which we were able to perform the standard delineations, three of the invertebrate delineations were at the same location as the standard delineations, five were on the wetland side, and four were on the upland side (Figure 3). Without exception, the relative elevations from our invertebrate delineations of temporary wetlands in cropland and grassland had lower standard deviations within wetlands than the elevations from our standard delineations (Figure 6).

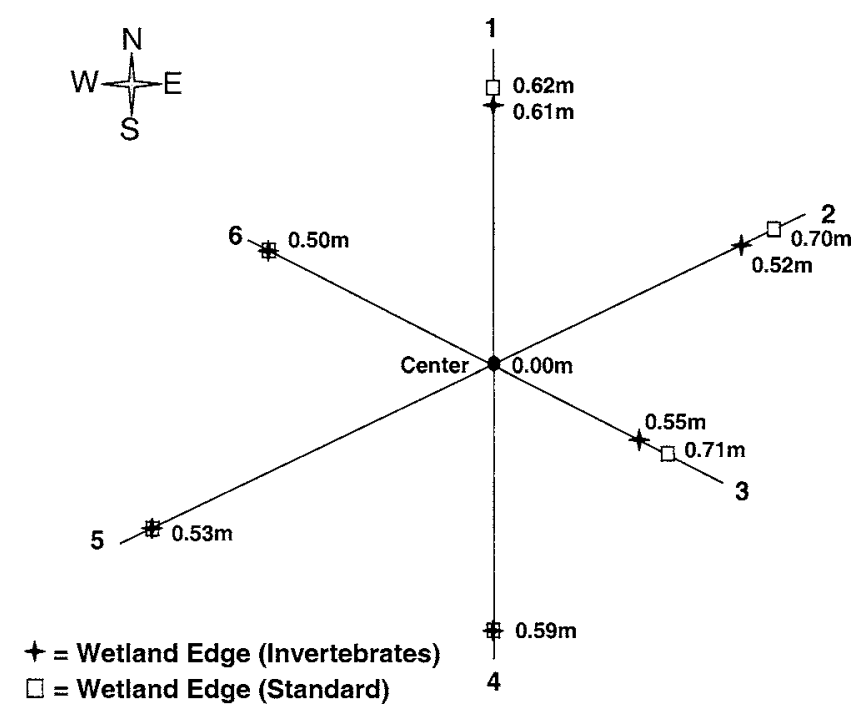

Figure 4. Relative elevations ( $m$ above center elevation) of invertebrate delineations and standard delineations along six transects in seasonal wetland SG5 depicting how invertebrate delineations were typically at the same locations as the standard delineations or were closer to the center of the wetland in grassland wetlands.

\section{DISCUSSION}

Just as the remains of aquatic invertebrates can be used to identify temporary and seasonal wetlands in the prairie pothole region (Euliss et al. 2001), they can also be used to refine delineations of these difficult-to-recognize wetland classes. Since aquatic invertebrates are strictly limited to areas of standing water and hydric soils and hydrophytes require only saturated soil conditions, it follows that invertebrate delineations will not overestimate wetland extent (i.e., they will fall at or below the elevation of standard delineations). Our delineations of the wetland edge using invertebrates were consistently at the same location as the standard delineations or closer to the wetland center for both seasonal and temporary wetlands in grassland; in grassland wetlands, we never found the remains of aquatic invertebrates outside of the wetland basin as delineated using standard indicators. Thus, while the presence of aquatic invertebrate remains is a reliable wetland indicator, the absence of remains does not always mean that the sample was collected outside of a wetland as defined by the standard delineation.

In wetland basins disturbed by agricultural tillage, the conservative relationship between the invertebrate delineations and the standard delineations broke down; many of our invertebrate delineations of seasonal and temporary wetlands in cropland were on the upland side of our standard delineations. A simple explanation is that invertebrate remains were transported higher in ba- 


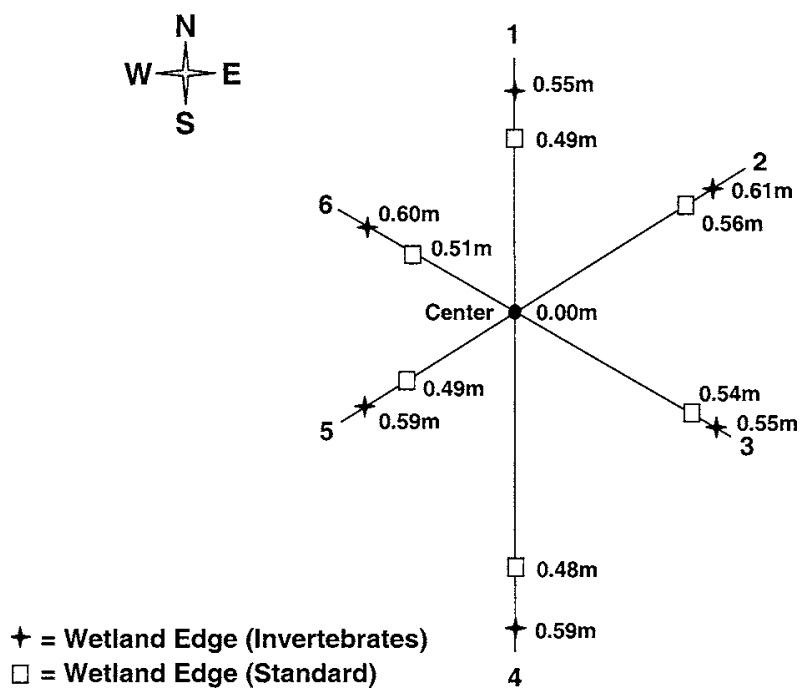

Figure 5. Relative elevations ( $m$ above center elevation) of invertebrate delineations and standard delineations along six transects in seasonal wetland SC2 depicting how invertebrate delineations were often farther away from the wetland center in cropland wetlands.

sins during the tillage process. However, additional factors may have contributed to the differences in delineations of grassland and cropland wetlands. Euliss and Mushet (1996) found that water-level fluctuations (the difference between maximum water level and minimum water level during a growing season) were greater in wetlands with tilled catchments than in wetlands with grassland catchments. They attributed part of this fluctuation to increased runoff from tilled catchments, resulting in deeper pool levels in cropland wetlands after major precipitation events. Such increases in pool depths would tend to deposit invertebrate remains at higher relative elevations in cropland wetlands relative to grassland wetlands. Similarly, van der Kamp et al. (1999) found that cultivated wetlands in the northern prairie region of Canada had lower pool levels after conversion to a brome/alfalfa mixture grassland than wetlands that remained in cultivation. They attributed the lower pool levels of wetlands in grassland areas to reduced runoff from spring snowmelt after conversion of the catchment back to grassland.

In addition to transportation during tillage and greater pool depth depositing invertebrate remains at higher elevations in cultivated wetlands, the inherent disturbance of the soils and plant communities resulting from tillage may have led to a migration of soil and plant indicators toward the wetland center and thus lowered the elevations of our standard delineations. In order to maximize production, agricultural producers routinely till and plant as much of a wetland's basin as water conditions permit. In temporary wetlands, this usually means the entire basin is cultivated. In seasonal

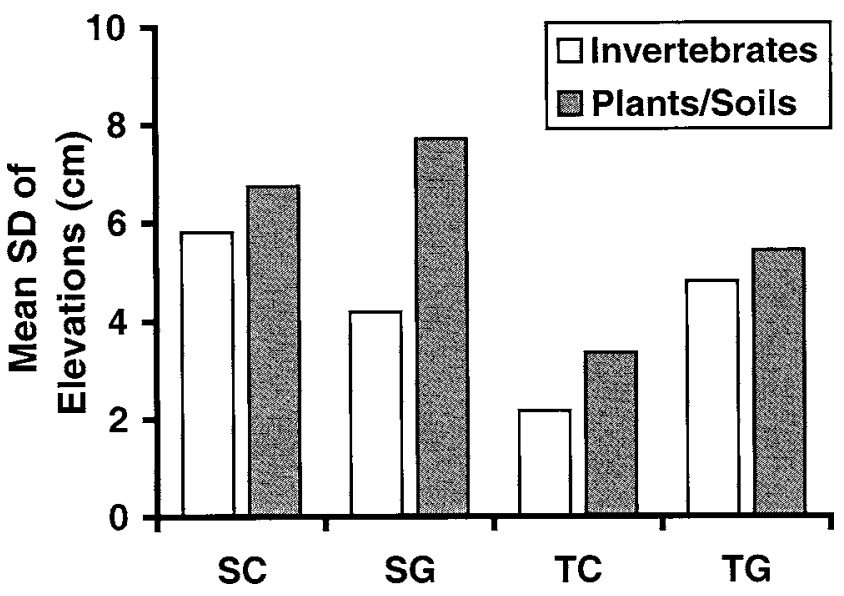

Figure 6. Mean standard deviation of elevations of invertebrate delineations and standard delineations for seasonal wetlands in cropland (SC), seasonal wetlands in grassland (SG), temporary wetlands in cropland (TC), and temporary wetlands in grassland (TG) in the glaciated plains of North Dakota.

wetlands, cultivation of the entire basin may not be possible in years with above-normal precipitation. However, even in wet years, outer margins of wetlands are usually tilled and planted, and the entire basin may be tilled for weed control if it dries later in the season. Kantrud and Newton (1996) found that over 77 percent of the area of all wet-meadow zones (the outermost wetland zone) in agricultural watersheds had recently been cultivated. This cultivation resulted in the wet-meadow zone of wetlands in agricultural landscapes having lower species richness and a greater percentage of unvegetated bottom as compared to wetlands in grassland landscapes. The direct disturbance of the soils and increased percentage of unvegetated bottom resulting from tillage of the outer zone of prairie wetlands may yield standard delineations closer to the wetland center in cropland wetlands than in grassland wetlands, where the soil and plant indicators are undisturbed.

The maximum elevation around a wetland at which invertebrate remains will be deposited should be closely related to the elevation of pool levels (a relatively level plane). However, soil and plant indicators may extend further into the upland due to ground-water mounds or seeps. Thus, the invertebrate delineations should be less variable than among standard delineations based on soils or hydrophytes. With only one exception (a seasonal wetland in cropland), we found this to be the case. In both temporary and seasonal wetlands, and in both cropland and grassland habitats, the elevations of the wetland edge based on invertebrate remains had lower standard deviations within 
wetland basins than delineations using standard methods. In the single wetland where the deviation of the invertebrate delineated elevations was greater, the difference was not due to an exceptionally high standard deviation among the elevations of the six invertebrate delineations $(5.9 \mathrm{~cm})$ but instead was the result of an especially low standard deviation $(1.2 \mathrm{~cm})$ among the elevations of the six standard delineations. The close relationship between invertebrate delineations and maximum pool levels supports our argument that invertebrate delineations will be closer to the wetland center than standard delineations if hydric soils and hydrophytes extend further into the upland due to ground-water influences.

As expected, we were unable to identify the wetland edge in some (three out of five) tilled temporary wetlands using standard hydric soil and vegetation indicators. The standard delineations in these wetlands failed due to the destruction of soil and plant indicators by agricultural practices such as tillage. However, in two of these three wetlands, our invertebrate delineations also failed to identify the wetland edge. Euliss and Mushet (1999) found greatly reduced numbers of aquatic invertebrate resting eggs and shells in tilled temporary wetlands. In their study, cladoceran resting eggs were completely absent from the soils in 14 of the 19 tilled temporary wetlands sampled, whereas cladoceran resting eggs were absent from only one of the 19 temporary wetlands sampled in grassland. The absence of invertebrate remains in some of our tilled wetlands further supports our conclusion that, while the presence of aquatic invertebrate remains is a reliable wetland indicator, the absence of remains does not always imply that the location is not within a wetland. While beyond the scope of most routine field delineations, incubation of samples in aquaria (Euliss et al. 2001) may provide additional information useful in identifying wetland boundaries.

Wetland delineation is an attempt to locate an exact point along a continuum of hydrologic, substrate, and biotic characteristics distributed from a wetland's center into the upland. Not only is this point indefinite, but it is also continually moving as wetlands expand and contract in response to normal interannual wet/dry cycles of the prairie pothole region. Land-use impacts resulting in increased fluctuations of water levels and the destruction and disturbance of soil and plant indicators in agricultural wetlands exacerbates our ability to delineate wetlands in the prairie pothole region accurately. Aquatic invertebrate remains provide an additional wetland indicator that can be used to delineate wetlands when other methods fail or are not feasible, especially in agricultural landscapes.

\section{ACKNOWLEDGMENTS}

We thank M. J. Hoff and A. Deutscher for helping with the collection of field samples and Q. Guo, J. W. LaBaugh, D. L. Nielsen, and two anonymous referees for providing critical reviews on an earlier version of this manuscript. Use of brand names in this manuscript does not constitute nor imply endorsement by the U. S. Government.

\section{LITERATURE CITED}

Barnes, R. D. 1968. Invertebrate Zoology, second edition. W. B. Saunders Company, Philadelphia, PA, USA.

Clarke, A. H. 1981. The Freshwater Molluscs of Canada. National Museum of Natural Sciences, Ottawa, ON, Canada.

Dahl, T. E. 1990. Wetland losses in the United States 1780's to 1980's. U.S. Fish and Wildlife Service, Washington, DC, USA.

Dahl, T. E. and C. E. Johnson. 1991. Status and trends of wetlands in the coterminous United States, mid-1970's to mid-1980's. U.S. Fish and Wildlife Service, Washington, DC, USA.

Euliss, N. H., Jr. and D. M. Mushet. 1996. Water-level fluctuation in wetlands as a function of landscape condition in the prairie pothole region. Wetlands 16:587-593.

Euliss, N. H. Jr. and D. M. Mushet. 1999. Influence of agriculture on aquatic invertebrate communities of temporary wetlands in the prairie pothole region of North Dakota, USA. Wetlands 19:578-583.

Euliss, N. H., Jr., D. M. Mushet, and D. H. Johnson. 2001. Use of macroinvertebrates to identify cultivated wetlands in the prairie pothole region. Wetlands 21:223-231.

Euliss, N. H., Jr., D. A. Wrubleski, and D. M. Mushet. 1999. Wetlands of the prairie pothole region: invertebrate species composition, ecology, and management. p. 471-514. In D. P. Batzer, R. B. Rader, and S. A. Wissinger (eds.) Invertebrates in Freshwater Wetlands of North America-Ecology and Management. John Wiley and Sons, Inc., New York, NY, USA.

Federal Interagency Committee for Wetlands Delineation. 1989. Federal manual for identifying and delineating jurisdictional wetlands. U.S. Army Corps of Engineers, U.S. Environmental Protection Agency, U.S. Fish and Wildlife Service, and U.S.D.A. Soil Conservation Service, Washington, DC, USA. Cooperative Technical Publication.

Kantrud, H. A. and W. E. Newton. 1996. A test of vegetation-related indicators of wetland quality in the prairie pothole region. Journal of Aquatic Ecosystem Health 5:177-191.

National Research Council. 1995. Wetlands-characteristics and boundaries. National Academy Press, Washington, DC, USA.

Reed, P. B. 1988. National list of plant species that occur in wetlands: National summary. U.S. Fish and Wildlife Service, Washington, DC, USA. Biological Report 88(24).

Stewart, R. E. and H. A. Kantrud. 1971. Classification of natural ponds and lakes in the glaciated prairie region. U.S. Fish and Wildlife Service, Washington, DC, USA. Resource Publication 92.

Tiner, R. W. 1984. Wetlands of the United States: current status and recent trends. U.S. Fish and Wildlife Service, Washington, DC, USA.

U. S. Army Corps of Engineers. 1987. USACE wetlands delineation manual. Environmental Laboratory, U.S. Army Corps of Engineers, Waterways Experiment Station, Vicksburg, MS, USA. Technical Report Y-87-1.

U. S. Department of Agriculture. 1994. National Food Security Act Manual: 3rd Edition. U.S.D.A., Soil Conservation Service, Washington, DC, USA. Part 519, 180-V-NFSAM.

U. S. Department of Agriculture. 1996. Field Indicators of Hydric Soils in the United States. G. W. Hurt, P. M. Whited, and R. F. Pringle (eds.). U.S.D.A., Natural Resources Conservation Service, Fort Worth, TX, USA.

U. S. Environmental Protection Agency. 1988. EPA Wetland Identification and Delineation Manual (two volumes). W. S. Sipple 
(ed.). U.S. Environmental Protection Agency, Office o Wetlands Protection, Washington, DC, USA.

U. S. Environmental Protection Agency. 1993. EMAP Project Descriptions. U.S. Environmental Protection Agency, Office of Research and Development, Washington, DC, USA. EPA/620/R-93/ 009. van der Kamp, G., W. J. Stolte, and R. G. Clark. 1999. Drying out of small prairie wetlands after conversion of their catchments from cultivation to permanent brome grass. Hydrological Sciences 44: 387-397.

Manuscript received 29 June 2001; revisions received 3 January 2002; accepted 11 January 2002. 